\title{
LANGUAGE STYLE OF HUMOR ON STAND-UP COMEDY VIDEO
}

\author{
${ }^{1}$ Merry Rullyanti; ${ }^{2}$ Nurdianto \\ 1, 2English Literature Department Faculty of Letters University of Dehasen \\ Corresponding email:merry.rullyanti85@gmail.com
}

\begin{abstract}
This research explained about language styles which used in stand-up comedy script brought by Chris Rock. Chris Rock owns famous joke material that is affected by the black comedy pioneers like Richard Pryor and Redd. He attacked the subject of much avoided by comics such as politics, race and celebrity. Openness and honesty witch extremely bold that what makes Chris Rock as one of the most successful and a famous comic in modern comedy. Chris Rock is known for his insulting comedian, he is also known for using satire and surreal in his joke. Language style has several functions in its uses. Stand-up comedy brought by Chris Rock is usually shows about the different in human right between black and white skins. Based on the description above, the researcher decided to research language style in stand-up comedy brought by Chris Rock. In this research the researcher uses Keraf (2007) to analyze the language styles. This research is a qualitative descriptive research. This research source of data is stand-up comedy script with tittle "kill the messenger" brought by Chris Rock. Based on research, there are 2 language styles used in "kill the messenger", there are 10 rhetorical language styles and 17 figurative language styles. Based on the data, hyperbole rhetorical language style is dominantly used in "kill the messenger". And Epithet figurative language is dominantly used too.The reason is because Chris Rock is still try to persuade the white skin American to be humble to black skin American and must respect to each other.
\end{abstract}

Keywords: Language Styles, Humor, Stand-Up Comedy

\section{INTRODUCTION}

Humor has been widely presented in various media forms of media such as audio and visual media. Additionally, humor can also contain in audio visual as in stand-up comedy. Stand-up comedy as one of the products of humor are rife discussed by the general public today can be interpreted as 'standing comedy' or 'single comedy'. Stand-up comedy has the specificity that jokes material brought on stage by comic in front of audience live.

There are some of the famous American comic that is Woody Allen, George Carlin, Margaret Cho, Jerry Seinfield, Eddie Murphie, and Chris Rock. The names above are very popular among their fans of stand-up 
comedy because of different character of joke in each material comedy. Chris Rock is own famous joke material that is affected by the black comedy pioneers like Richard Pryor and Redd. He attacked the subject of much avoided by comics such as politics, race and celebrity. Openness and honesty witch extremely bold that what makes Chris Rock as one of the most successful and a famous comic in modern comedy. Chris Rock is known for his insulting comedian, he also known for using satire and surreal in his joke. Because of above reasons, researcher chose Chris Rock as the target of research.

According to researchers explained above, language style can be used in many aspect, but still the function is to attract the listener. In comedy language style is used in different type of jokes, different people will use different language style, language style will become of the characteristics of the comedian. Then, humor emerged by Chris Rock is inseparable from the linguistic aspects of creating humor especially style of language. The use of style language on humor often appear suddenly and appeared as a result of an individual's expertise of comedian about using the language style both orally or written to inflict funny effect about humor that performed. Every comedian has own language style and there are no standard rules in electoral style that displayed.

A discussion of the use of language style is not a new thing. According to Keraf (2009: 115) language style can be review from various points of views, the perspectives or opinions on language style at least can be distinguished from linguistic and non-linguistic. In the utterance of humor in stand-up comedy video performed by Crish Rock linguistic aspect is a major construction to support his action on the stage, unique wordplay and attractive that showed by Chris Rock be able to get response laughter from the audience. Chris Rock has its own tricks to provoke laughter language style that is used also varies in delivering the story of humor. One style of language he uses is hyperbole. This has become one of the weapons to support the creation of incredibly humor effect.

Considering all the reason above, the researcher selected stand-up comedy video "kill the messenger" As a research object. Unique wordplay as a tool of humor that become concern the researcher to discover language styles are used to create humor in stand-up comedy video "kill the messenger" performed by Chris Rock. Chris Rock is the fifth ranked as stand-up comedian according to toptens.com. They are not so many black skin comedian and researcher chose Chris Rock based on the comments on the site. 


\section{METHODS}

The research design will use descriptive qualitative approach. Tarigan (2012) states that descriptive is a writing that can illustrate a story and purpose of the description is to invite readers to be able to understand, feel, and enjoy the objects discussed such as mood, activity and so forth while Moleong (2017) qualitative research is a study used to investigate, discover, describe, and explain the quality or privilege of unexplained social influence, measured or illustrated by quantitative approach. The data will be taken from video script including the playing time, data will be taken from sentences spoken by Chris Rock.Researcher in collecting data will read the comedy script, then listing which words or sentences categorized as language style.

\section{FINDINGS}

\section{Language Style Used in "Kill the Messenger"}

Researcher found there are fourteen utterances use rhetorical language style. As mentioned by Keraf (2010), rhetorical language style means deviation from common construction to reach certain effect, the function can be varied such as explain, strengthen, revive non-alive object, provoke, laughs and decorate sentences. In "Kill the Messenger" script spoken by Chris Rock (CR), most of his comedy contains many purposes, but his main purpose is to support or ask his watcher to support Barrack Obama as US next president. According to main characteristic of America people where they have a right to talk free, Chris Rock sarcasm the president directly. Because of that, even there are more than a thousand utterances, only few utterances considered using rhetorical language style. The detail information about rhetorical language style can be seen in table below.

Table 1. Rhetorical Language Style in CR Script

\begin{tabular}{clc}
\hline No & \multicolumn{1}{c}{ Rhetorical Language Style } & Total \\
\hline 1 & Apostrophe & 1 \\
2 & Periphrasis & 1 \\
3 & Prolepsis $\quad$ Total & 1 \\
& & 3 \\
\hline
\end{tabular}

\section{Apostrophe}

First finding in Chris Rock utterance can be found in data 1019, it is considered as Aposthrope, CR said "That's the universal big-dick greeting Like" Hey Hey welcome to Pussonia"". Word Pussonia cannot be found in any dictionary (general dictionary) the reason is because it is not general word which used in speaking normally. Pussonia word is a modification from word pussy. Word Pussy can have different meaning depends on the purpose of the use, for example "don't act like a pussy", that utterance use 
word pussy, and the word itself means coward. In foul language, pussy means woman genital, some of American use that word to praise woman genital for example, "nice pussy", some other use this word refers to a naughty girl or call girl but some other use it as a friendly name for female friend. So, word Pussonia can be refer to a country or a name of bar or café with naughty woman as a service. In the script, the researcher only found one Apostrophe.

\section{Periphrasis}

In data 183, researcher found Periphrasis utterance, CR said" it's going to be hard for Barrack Obama to be President, man". Periphrasis means longer sentence than usual, it is about using the different way longer to express something, CR can use will instead of going to be. CR uses going to be because he believes it is something really happened, CR believes Barrack Obama way to be a president will be blocked and what CR said is true because if Barrack Obama want to be a president, he will be the first black skin president and for people who always racist to other, they will try to oppose him. Researcher only found one Periphrasis utterance.

\section{Prolepsis}

According to research, researcher found two utterances categorized as prolepsis, for example at data 118, CR said "They will change all this shit", and at data 338 "soon they're going to start selling gas in bars. Sentence They will change all this shit means the persons will move all. This sentence prolepsis meaning, it is impossible to make a woman pregnant just getting close without doing nothing.

\section{Hyperbole}

According to research, researcher found eight utterances categorized as hyperbole, for example at data 206, CR said "It's my fucking wife, man, she's gonna kill you", sentence she's gonna kill you is hyperbolize the utterance, the purpose is to make someone afraid doing something. Another example at data 270 when CR said" They know they gaining weight when too many black guys start hitting on 'em", the word they refer to white woman, CR means white people believe that every time white woman get close to black people especially man, can make them pregnant. This sentence hyperbolizes the meaning, it is impossible to make a woman pregnant just getting close without doing nothing.

Table 2. Figurative Language Style in CR Script

\begin{tabular}{ccc}
\hline No & Figurative Language & Total \\
\hline 1 & Epithet & 8 \\
\hline
\end{tabular}




\begin{tabular}{clc}
\hline No & \multicolumn{1}{c}{ Figurative Language } & Total \\
\hline 2 & Synecdoche & 1 \\
3 & Irony & 3 \\
4 & Sarcasm & 4 \\
5 & Inuendo $\quad$ Total & 1 \\
& & $\mathbf{1 7}$ \\
\hline
\end{tabular}

\section{Epithet}

First finding is epithet, epithet is a descriptive literary device that describes place, a thing, a person, in such a way that it helps in making the characteristics of a person. In this research the researcher only found one sentence which categorized as epithet. It can be found in data 36 when CR said" And I saw a bunch of white people taking pictures of me", CR use white people to describe about American who have white skin, racist is a problem in America, another example about epithet sentence can be found in data-40, CR said" and they're like, "Ah, chicken bone. 13 miles to the left, niggers will be there."', CR said word "nigger", nigger is a nickname for black skin people, same as with "yellow" for Asian or Chinese people. White skin American thought all black skin people come from Nigeria eve thought they know that not all black skin not from Nigeria especially when they were born and live since toddler in America. Another example can be seen at data 82 when CR said" This motherfucker been telling the same story for 40 fuckin' years.". CR uses word "the motherfucker" to address someone which he doesn't like for telling same story for 40 years. This word is really popular word, motherfucker word is used to someone who made someone angry, someone who weak also for enemy. There are eleven sentences categorized using epithet language style.

\section{Synecdoche}

Researcher also found only one synecdoche in the script, it can be seen in data 45, CR said" Big election year in the United States", Synecdoche is a literary device in which a part of something represents the whole or it may use to represent a part. In this case, words United States in represent all countries in America continent.

Researcher also found seventeen figurative language style, but researcher only found four kind of figurative language style in CR stand-up comedy script. The detail about figurative language can be seen in the table below.

\section{Irony}

Researcher also found the utterance use irony in a sentence, it can be found in data 430, CR said "Do you know what a black dentist would have to do to 
move into my neighborhood?" the CR use black dentist to mock the racists, it means that there is a different thing between how white skin dentist move to the neighborhood must be different and easier compared to black skin dentist. The researcher found only four utterance using Irony.

\section{Sarcasm}

Researcher found six utterance which categorized using sarcasm language style. Sarcasm is a form of verbal irony that mocks, ridicules, or express contempt. For example, in data 321, CR said" Bush is unbelievable, man. This guy's unbe-fucking-lievable". This sentence can be considered also as irony but it goes to sarcasm because it is in verbal expression. Normally that utterance looks like CR praise Bush, but he intends the opposite, he mock Bush for his rule as president. The use of irony or sarcasm usually hide the true intention, negative meaning with positive sentence. Another example for sarcasm can be found at data 847, CR said" That's right. Pussy's like Visa, accepted everywhere", this utterance mocks sex worker is like a visa, accepted everywhere. As mentioned before about pussy's meaning, sex worker same like visa, they can be accepted everywhere.

\section{Innuendo}

Researcher also found one Innuendo language style in $C R$ script, for example, in data 468, when CR said" You scream "nigger" and I'll raise interest rates". This utterance insult how white skin America underestimated black skin America. There are so many privileges for white skin America but it is not for black skin, from above utterance, black skin America mostly treated as a black goat, when a group of people consist black and white skin American, and a mistake was done by white skin America, the blame would be addressed to black America, the reason is because the racist in overview everything is still high and still problem.

\section{Dominant Language Style in "Kill the messenger".}

Based on the finding by the researcher, researcher found that in "kill the messenger" stand-up comedy script brought by Chris Rock, he mostly used figurative language style, there are 17 figurative styles. It is clear in "kill the messenger", most utterances refer to a comparison between black and white skin privilege. The different human right for black people the reason is because many utterances concludes white and black and show how white skin discriminates the black skin for example like they know they (white skin women) were going a date with black skin men will make them pregnant (gain weight meaning) and epithet is a figurative language which used the most.

In rhetorical language style, hyperbole is a style which have been used the most, it means CR like to say something over than normal 
condition to attract the audiences respond. Some foul language is also used to shown his deeply feeling. Not only in "kill the messenger" in his other stand-up comedy with different title like "blacker" CR said, "you could be the worst mama on earth", this utterance is hyperbole because researcher believes that there will be the worst other than her mama.

In Figurative language style, Epithet language style is the dominant used by $C R$, there reason because $C R$ type of comedian by criticizing or mock someone even president. The word "nigger" and "Black people" also come out at his other tittle of his stand-up comedy like in "Nigger vs Black people".

\section{DISCUSSION}

According to findings, the result of this research is analyzed to answer the research question. Analyzing process is done by connecting findings and theory. According to Keraf (2007), there are two kind of language styles, Rhetorical language style and Figurative language style. Each language style has many subs, for example Rhetorical language style has 10 styles and Figurative language style has 17 styles. There are 1149 utterances which spoken by Chris Rock in his stand-up comedy with tittle "Kill the Messenger". But from 1149 utterances, researcher only found few utterances using language style, the rest of them is using regular utterance with direct message. In this part findings are analyzed based on the finding in a paragraph.

CR was well known for his career as a comedian, he received two Emmy Awards and obtained large critical acclaim. In his standup comedy with tittle Niggas vs Black people, one of CR utterances to show social problem between white and black skin people is "Everything white people don't like about black people". CR also known for his rough comedy, it means he mostly uses foul language and adult language in his comedy like in his comedy with tittle "Love" he said "you can fuck a woman with a diamond dick and make a cup in time, she'll still complaint why you made me cum so hard".

The audience also loves his comedian language style for example like a comment from Josh Araujo in "Love", "If you look very closely between all the foul language and the gruff voice, this man makes more sense than your Philosophy textbook" it means all of CR utterance is more meaningful than philosophy book about woman and love. A comment also comes from Ali rm84, "I swear he is $100 \%$ right, I have been with all kinds of cultures and nationalities and I have never met a happy woman in my life..." means he believes what CR said about women for all nationality or cultures are same.

Data shows that there are 15 rhetorical language styles and 23 figurative language styles. Based on the data, CR stand-up comedy with title 
"Kill the messenger" means to compare or showing similarities. it can be seen from how he tried to blow racist problem in America, he compared how white skin American privilege is different with black skin American. He also exposed how bush ruled American and he also tried to ask the audience to support the first black skin president candidate in next president election.

In rhetorical language style, hyperbole is a style which have been used the most, it means CR like to say something over than normal condition to attract the audiences respond. Some foul language is also used to shown his deeply feeling. Not only in "kill the messenger" in his other stand-up comedy with different title like "blacker" CR said, "you could be the baddest mama on earth", this utterance is hyperbole because researcher believes that there will be the baddest other than her mama.

In Figurative language style, Epithet language style is the dominant used by CR, there reason because $C R$ type of comedian by criticizing or mock someone even president. The word "nigger" and "Black people" also come out at his other tittle of his stand-up comedy like in "Nigger vs Black people".According to finding, researcher believes that in order to attract audience and to make his comedy became has characteristic, he uses figurative language than rhetorical, the reason is because CR used to blow topic about racism and different treat by other people also use foul language in every comedy.

From finding the data and analyze it, researcher found something interesting in $\mathrm{CR}$ script, it can be categorized as Rhetorical-Figurative language style or mix of 2 styles. The reason is because it is possible to mix two styles in one utterance like sarcasm-hyperbole.

\section{CONCLUSION AND SUGGESTION}

Based on the findings data, the analyze the data the researcher believes that Chris Rock in "Killer the messenger" standup comedy uses figurative language style, the reason is because CR always choose the conflict or racism between black skin and white skin in United States. Most content of CR stand-up comedy is about criticizing the government and how white skin people treat black skin people low also use foul language as his comedy characteristics.

\section{REFERENCES}

Cooper, C. (2008). Elucidating the Bonds of Workplace Humor: A Relational Process Model. Human Relations, 61, 1087-1115.

Crawford, M. (2003). 'Gender and humour in social context.' Journal of Pragmatics, 35, 1413-1430.

Dynel, M. (2013). Humorous Phenomena in Dramatic Course. Poland:

University of Lodz 
Merry Rullyanti, Nurdianto

Fauconnier, G. \& Turner, M. (1995). “Conceptual Integration and Formal Expression". Metaphor and Symbol 10 (3): 183-203.

Freud, S. (1960). Jokes and their relation to the unconscious (J. Strachey, Trans).

New York:

Greene, G. F. (2012). Rhetoric Comedy: How Comedians Use Persuasion and How Society Uses Comedians. Hancock: Goerge College \& State University.

Longman Advanced American Dictionary. (2003). Longman Advanced American Dictionary. New York: Pearson Education. 